\title{
CFD 解析を用いた全電化学校給食施設の各季節における適正換気量の検討 STUDY ON THE SEASONAL APPROPRIATE VENTILATION RATE IN AN ALL ELECTRIC CENTER OF PROVIDING SCHOOL LUNCH BY CFD ANALYSES
}

\author{
島本裕子*，村川三郎**，西名大作**，青野政信**** \\ 宇 草 和 義 $* * * *$, 花園 新太郎 $* * * * *$ \\ Yuko SHIMAMOTO, Saburo MURAKAWA, Daisaku NISHINA, \\ Masanobu AONO, Kazuyoshi UGUSA and Shintaro HANAZONO
}

\begin{abstract}
All electric cooking equipments have been propagated in the center of providing school lunch. However, the ventilation rates of the facilities are well planned with the same criterions applied for the facilities equipped by gas combustion cooking ranges because we do not have definite planning standards on the ventilation rates.

The purpose of this study is to clarify the possibility of the ventilation rate reduction in the cooking room of an actual center of providing school lunch. First, by the comparison between the results of the experiments and the CFD analyses in summer, the applicability of CFD analysis was confirmed. Second, based on the comparison among the results of the CFD analyses in case of the various ventilation rates included 20 times per hour as the initial value, the ventilation rate can be reduced $30 \%, 20 \%$ and $50 \%$ of the initial value in summer, winter and middle season, respectively.
\end{abstract}

\section{Keywords : All Electric Center of Providing School Lunch, Electric Cooking Equipments, Ventilation Rate, Thermal Environment, Energy Consumption, CFD Analysis 全電化学校給食施設, 電気調理機器, 換気量, 温熱環境, 電力消費量, 数値流体解析}

\section{1. 序}

学校給食施設では 1996 年の病原性大腸菌 O-157 による集団食中 毒の発生を契機として, 食品安全衛生や労衝衛生環境に関する関心 が高まり, HACCP の衛生管理ガイドラインに基づく欴房内の環境 整備が図られている。しかし, 剭房内の徹底した温湿度管理が要求 される一方，それによって換気・空調エネルギーは増大しており， 厨房内の計画・設計においては, 高い省エネルギー性と, 快適な㕌 房内環境の創出が強く望まれている。

近年，ガス厨房では低放射・集中排気型厨房機器の導入等による 放射環境および空気環境の改善がなされている 1)。また，並行して 調理における制御性が高く，裸火を使用しないためふく射熱の抑制 が可能な電化厨房機器を導入する施設も増加している。これらの機 器導入は厨房内の換気・空調設備設計にも多大な影響を及ぼし，ま た適切な換気量および温湿度の管理は, 省エネルギー性に高く寄与 すると考えられる。

電化旡房の換気量については, 国土交通省が監修した建築設備設 計基準 (平成 21 年版) 2 ) には「各器具の電気容量による有効換気量 $\left(30 \mathrm{~m}^{3} /(\mathrm{h} \cdot \mathrm{kW})\right.$ 以上), 各排気フードの面風速 $(0.3 \mathrm{~m} / \mathrm{s}$ 以上) から 算出した換気量の合計值, 室の換気回数 $(20$ 回/ $\mathrm{h}$ 以上 $)$ から算出 した換気量等を満足する值」と示されているものの，電化欴房にお ける適切な計画・設計方法は未だ充分に確立されていないことから， 実際には過大な換気量で設計される例も少なくない。したがって, 電化厨房の適切な換気・空調計画方法を策定寸るには，実際に建設 された施設を対象として, 実験や CFD 解析を実施することで, 有 用な資料を獲得することが重要であると考えられる。

学校給食施設の厨房内温熱環境を実測した既往の研究として，ガ ス厨房および電化欴房を対象に，それぞれの厨房内温熱環境を実測 調査により明らかにした宇野ら 3) が挙げられる。また, 村川ら 4) が, 天井型の換気システムを有する施設を対象に, 欴房機器からの発生 負荷や空調吹き出し気流が欴房内温熱環境に及ぼす影響について検 討している。しかしながら，これらはいずれも換気量を一定值に固 定しての検討であり, 同一施設を対象に複数の換気量条件を設定し， 各条件がもたらす影響を比較・検討することによって，それら換気 量の妥当性を検証するまでには至っていない。

\footnotetext{
本論文は，2007年度日本建築学会中国支部研究発表会(広島）２２008年度日本建築学会中国支部研究発表会(島根），2009年度日本建築学会中国支部研究発表会(広島)に执いて発 表した内容に基づいて加筆・修正したものである。

兰機工業侏) 修士(工学) (当時 広島大学大学院工学研究科 大学院生)

** 広島大学 名誉教授.工博

*** 広島大学大学院工学研究科 教授・博士 (工学)

**** 四国電力(秼)土建築部

***** ダイダン(株) 修士(工学)

(当時 広島大学大学院工学研究科 大学院生)
} 
一方, 厨房に関する CFD 解析については, 本多, 甲谷ら 5) はガ スコンロを対象に, 鍋上部における熱上昇流の解析精度の向上を目 的に, 鍋側面に温度・風速を規定するモデル化手法を提案している。 他には, 荻田ら 6) がレストラン征房を対象に種々の換気・空調方式 による排気フードの捕集性状について評価しており, 村川ら 7) は広 島大学建築環境学実験棟に建設した実験室をモデル化し, トップフ ード型排気システムや天井型排気システムの熱除去率や温熱環境に ついて検討している。しかしながら, これらは単体の征房機器に個 別の排気フードを架ける場合を想定しているものが多く, フードを 設けず, 発生負荷を上部空間に滞留させてから排気するような大空 間を有する施設を対象としたものは少ない。

本研究は, 高天井を有し, インバータにより厨房内の換気量を変 更可能にした実際の全電化学校給食施設を対象として, 複数の換気 量条件について CFD 解析を行う。すなわち, 換気量を前述した基 準に従った $30 \mathrm{Q}(\mathrm{Q}$ : 機器の定格電気容量)にした場合, あるいは, それ以下の場合を設定し, 解析結果を比較・検証することにより, 換気量の削減可能性についての基礎的資料を得ることを目的とする。

はじめに, CFD 解析における解析モデルの妥当性について検討す るため, 夏期に調理室を対象として, 換気量を施設運用開始時の換 気量（初期換気量）より低減して実施した模擬負荷実験の結果を示

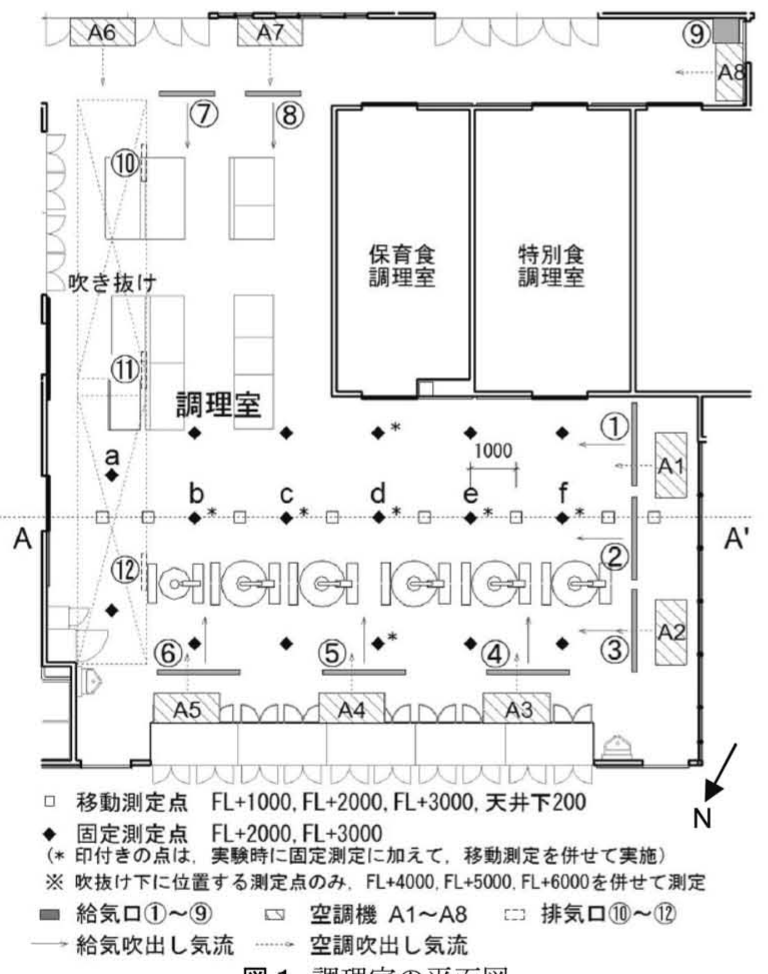

図 1 調理室の平面図

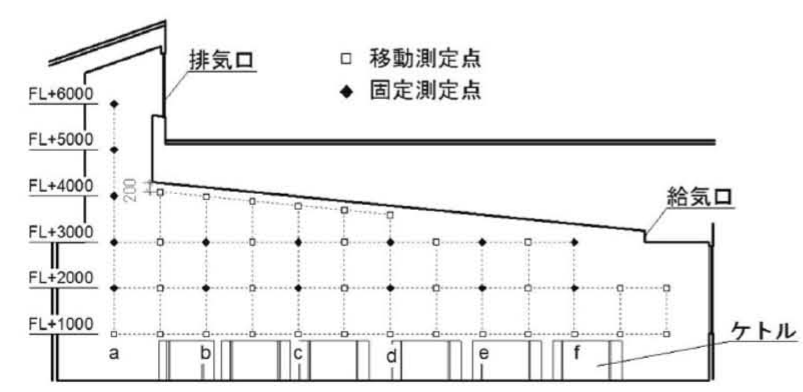

図 2 調理室の断面図 (A-A'断面)
し, 同一条件を与えた場合の解析結果と比較する。これにより, 設 定した境界条件等による CFD 解析の適用性を確認する。そのうえ で, 各季節 (夏期・冬期・中間期), 各換気量条件下における解析を 行い,それぞれの外気条件下における最適換気量について検討する。

\section{2. 施設概要}

対象施設は平成 19 年 4 月から実運用を開始した香川県の全電化 学校給食施設であり, 平均 1 日当たり 2150 食, 最大 2300 食を提供 可能な, 給食施設として一般的な規模である。施設概要を表 1 に示 す。本施設は, 下処理・調理・洗浄作業ごとに区画が分けられてい るが, 本研究では, 施設中央に位置し, 諸室に囲まれている調理室 を対象とする。図 1 , 図 2 に調理室の平面図および断面図を示す。

図 2 より, この調理室は高天井を有しており, 各調理機器からの 発生熱負荷を吹抜け上部からまとめて排気するため, 機器個別の排 気フードを有していないことが特徴として挙げられる。

換気システムは第一種機械換気で, 給気口(1) (9)より外気が直接 導入され, 排気口(10) (12)より排出されている。給気と排気の設計風 量は等しく, $13500 \mathrm{~m}^{3} / \mathrm{h}$ である。また, 空調はパッケージ方式で, $\mathrm{A} 1 \sim \mathrm{A} 8$ の 8 台の空調室内機が設置されている。

調理室内の主要機器を表 2 に示す。調理機器としては, 電気クッ キングケトル (以下ケトル) $27.0 \mathrm{~kW}$ が 5 台, 補助用の $13.5 \mathrm{~kW}$ が 1 台, 電気スチームコンベクションオーブン（以下スチコン） 1 台 がそれぞれ設置されている。

\section{3. 換気量条件の検討}

はじめに, 模擬負荷実験および CFD 解析に適用する換気量条件 について検討した。調理室の初期換気量は，事前に実施した換気量 測定の結果注 1 ) から, 室全体で $13276 \mathrm{~m}^{3} / \mathrm{h}$ (初期換気量) が得られ た。この值は, 換気回数が 20 回/h となるよう設定された, 施設の 設計換気量 $\left(13500 \mathrm{~m}^{3} / \mathrm{h}\right)$ にほぼ対応している。しかしながら, 本調 理室は高天井型であるため, 室容積が大きく換気回数に基づく換気 量では過大となる可能性がある。したがって, 設定する換気量条件

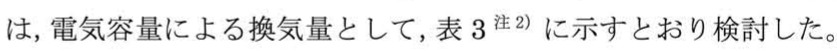

表 1 施設概要

\begin{tabular}{|c|c|c|c|c|}
\hline \multirow{3}{*}{ 留 } & 敷地 & $3305.8 \mathrm{~m}^{2}$ & 厨房方式 & ドライシステム* \\
\hline & 延床 & $1579.8 \mathrm{~m}^{2}$ & 調理熱源 & 電気 \\
\hline & 調理室 & $185.0 \mathrm{~m}^{2}$ & 換気方式 & 第一種機械換気方式 \\
\hline \multicolumn{2}{|c|}{ 構造 } & 鉄骨造 平屋建て & 空調方式 & パッケージ方式 \\
\hline
\end{tabular}

表 2 主要機器概要

\begin{tabular}{|c|c|c|c|c|}
\hline & 設置室 & 機器名称 & \begin{tabular}{|c} 
定格電気容量 \\
{$[\mathrm{kW}]$}
\end{tabular} & 台数 \\
\hline \multirow{2}{*}{ 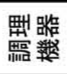 } & \multirow{2}{*}{ 調理室 } & 電気クッキングケトル & 148.5 & 6 \\
\hline & & 電気スチームコンベクションオーブン & 36.8 & 1 \\
\hline \multirow{4}{*}{ 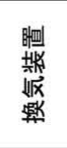 } & \multirow{2}{*}{ 調理室 } & 給気ファン & 3.7 & 1 \\
\hline & & 排気ファン & 0.8 & 3 \\
\hline & \multirow{2}{*}{ その他 } & 給気ファン & 16.7 & 8 \\
\hline & & 排気ファン & 10.4 & 60 \\
\hline \multirow{3}{*}{ 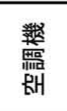 } & 調理室 & 個別分散型パッケージエアコン室内機 & 1.8 & 8 \\
\hline & その他 & 個別分散型パッケージエアコン室内機 & 10.2 & 59 \\
\hline & - & 個別分散型パッケージエアコン室外機 & 158.4 & 4 \\
\hline
\end{tabular}

※ 複数台ある機器は定格電気容量の合計を示す 
調理室に設置されている全ての加熱機器の合計定格容量に基づく換 気量は, $5559 \mathrm{~m}^{3} / \mathrm{h}$ となり, 初期換気量の $41.9 \%$ となった。ただし, スチコンは加熱機器に含まれるものの, 負荷の発生が調理終了時の わずかな時間に限定され,施設運用日の半数では使用されていない。 したがって, 毎日使用され, 同時に複数台が稼働するケトルのみを 加熱機器と捉えるなら, 換気量は $4455 \mathrm{~m}^{3} / \mathrm{h}$ となり, これは初期換 気量の $33.6 \%$ に相当する。さらにケトルの場合, 高出力での長時間 稼働はほとんどみられないことから, 60 分平均出力の最大值（出力 $92.4 \mathrm{~kW})$ を定格電気容量とみな寸なら, 換気量は $2773 \mathrm{~m}^{3} / \mathrm{h}$, 初 期換気量の $20.9 \%$ にる。

以上の結果から, 初期換気量の $100 \%$ と $30 \%$ の 2 条件について, 模擬負荷実験, 並びに, CFD 解析を行い, 両者を比較することとし た。さらに CFD 解析においては, 空調機の稼動による減湿が期待 される夏期, 外気湿度が低下する冬期について, さらなる換気量削 減となる $20 \%$ 条件に加えた。また, 空調機が稼動しない中間期は 空調負荷の増大がないことから, 安全側となる $50 \%$ を加えた。

\section{4. 模擬負荷実験の概要}

模擬負荷実験は, 各換気量条件において, 調理機器を連続的に使 用する際に想定される最大負荷を模擬的に与えた場合の室内温熱環 境の把握を意図している。表 4 に実験ケースを示す。初期換気量条 件(換気量割合 $100 \%$ ) は, 平成 19 年 8 月 21,22 日, 換気量割合 $30 \%$ は, 平成 20 年 8 月 19,20 日の，いずれも夏期に行った注 3$)$ 。

模擬負荷は, 補助用ケトルを除く定格電気容量 $27 \mathrm{~kW}$ のケトル 5 台を用い, ほぼ満杯に注いだ水道水を $95^{\circ} \mathrm{C}$ 前後まで定格出力で一旦 加温し, その後, 出力を $15 \%$ 程度に下げて水温がほぼ一定になった 状態を維持した。なお，減少した水分の補充はしていない。

模擬負荷実験時の測定項目を表 5 に示す。調理室内において温湿 度および風速を計測しており, 測定点位置については図 1 , 図 2 を 参照されたい。なお，換気量を初期換気量以下とする場合には, 図 1 に示す給気口(4) (7)を閉鎖している。

\section{5. 解析概要}

調理室の解析対象モデルを図 3 に示す。給排気口および空調機の 位置は本施設とほぼ同一で, 給気口(9)以外いずれも水平吹出しであ る。また, 実際のケトルは円形であるが, 解析では格子分割数を減 らすため, 実物と同様の表面積を有する直方体とした。調理室全体 を格子分割しており, 約 280 万メッシュとなる注 4 )。

模擬負荷実験と CFD 解析の比較 (6 章), および各季節・各換気量 条件下での解析 (7 章)においては, ほぼ同様の境界条件を用いている が, 給気温湿度, 並びに, 負荷発生条件は異なっている。表 6 に解 析条件を, 表 7 に解析ケースをそれぞれ示す。解析ソフトは STREAM, 乱流モデルは標準 $\mathrm{k}-\varepsilon$ モデルで, 移流項差分スキームは QUICK を用いた注 5)。壁面条件は, 気流を一般化対数則とし, 床, 天井，壁，ケトル側面等ではそれぞれ熱移動の条件を設定した。

実験結果との比較の際に用いる発生負荷は, 実験時の電力消費量 と給排気温湿度の測定結果に基づき決定した。各季節の解析で用い る発生負荷は, 実験時と同様に熱と水分をケトル水面から発生させ ることとしたが，発生熱量は，温湿度測定データから算出した実運 用時における給気並びに排気の熱量の差および村川ら 8)の研究に
よる模擬負荷実験の発生熱負荷を比較し，条件とする值を最終的に 決定した注6)。

なお，排気口横に位置する採光用の高空からの日射負荷について は，空が吹抜け上部に位置し面積が小であることから，室内の温熱 環境に及ぼす影響が比較的小さいものと考え，考慮していない。

表 3 換気量条件の検討項目

\begin{tabular}{c|c|c|c|c}
\hline \multicolumn{2}{c|}{ 検討項目 } & $\begin{array}{c}\text { 出力 } \\
{[\mathrm{kW}]}\end{array}$ & $\begin{array}{c}\text { 換気量 } \\
{\left[\mathrm{m}^{3} / \mathrm{h}\right]}\end{array}$ & $\begin{array}{c}\text { 換気量割合 } \\
{[\%]}\end{array}$ \\
\hline \multirow{3}{*}{ 定格電気容量 } & 全機器*1 $^{*}$ & 265.9 & $7976(43 Q)$ & 60.1 \\
\cline { 2 - 5 } & 加熱機器 $^{* 2}$ & 185.3 & $5559(30 Q)$ & 41.9 \\
\cline { 2 - 5 } & ケトル $^{* 3}$ & 148.5 & $4455(24 Q)$ & 33.6 \\
\hline \multirow{2}{*}{$\begin{array}{c}\text { ケトルの日平均 } \\
\text { 出カの最大値 }\end{array}$} & 15分間隔 & 133.4 & $4001(22 Q)$ & 30.1 \\
\cline { 2 - 5 } & 30分間隔 & 102.1 & $3062(17 Q)$ & 23.1 \\
\cline { 2 - 5 } & 60分間隔 & 92.4 & $2773(15 Q)$ & 20.9 \\
\hline
\end{tabular}

*1 サイノ目切り機やカートイン消毒保管庫等を含む調理室に設置された全ての機器 *2 スチームコンベクションオーブン( $36.8 \mathrm{~kW} \times 1$ 台), ケトル(13.5kW $\times 1$ 台, $27 \mathrm{~kW} \times 5$ 台)

*3 ケトル $(13.5 \mathrm{~kW} \times 1$ 台, $27 \mathrm{~kW} \times 5$ 台 $)$

$* 4$ 換気量割合は初期換気量 $13276 \mathrm{~m}^{3} / \mathrm{h}$ に対する割合を示す

表 4 模擬負荷実験ケース

\begin{tabular}{c|c|c|c|c|c}
\hline Case & 空調 $^{* 1}$ & $\begin{array}{c}\text { 換気量割合 } \\
{[\%]}\end{array}$ & $\begin{array}{c}\text { 換気量 } \\
{\left[\mathrm{m}^{3} / \mathrm{h}\right]}\end{array}$ & 測定日 & $\begin{array}{c}\text { 平均外気温度 } \\
{\left[{ }^{\circ 2} \mathrm{C}\right]}\end{array}$ \\
\hline B100 & 無 & 100 & 13276 & $\mathrm{H} 19.8 .21$ & 30.9 \\
\hline B30 & 無 & 30 & 3983 & $\mathrm{H} 20.8 .19$ & 29.3 \\
\hline D100 & 有 & 100 & 13276 & $\mathrm{H} 19.8 .22$ & 31.7 \\
\hline D30 & 有 & 30 & 3983 & $\mathrm{H} 20.8 .20$ & 29.9 \\
\hline
\end{tabular}

空調の設定温度は, 外気負荷の大きい換気量割合 $100 \%$ の条件では $19^{\circ} \mathrm{C}$ (設定可能

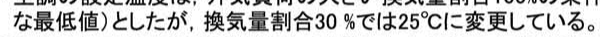

*2 実験実施中に高松地方気像台で観測された平均外気温度を示す。

表 5 模擬負荷実験の測定項目

\begin{tabular}{|c|c|c|c|c|c|c|}
\hline & 測定項目 & $\begin{array}{l}\text { 測定対象 } \\
\text { - 点数 } \\
\end{array}$ & $\begin{array}{l}\text { 測定 } \\
\text { 機器 }\end{array}$ & $\begin{array}{l}\text { 機器 } \\
\text { 製造元 }\end{array}$ & $\begin{array}{l}\text { 測定 } \\
\text { 時間 }\end{array}$ & $\begin{array}{l}\text { 測定 } \\
\text { 間隔 }\end{array}$ \\
\hline \multirow{2}{*}{ 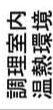 } & $\begin{array}{l}\text { 移動測定 } \\
\text { 温湿度·風速 }\end{array}$ & 作業環境 53点 & Testo 454 & (株テテ자ー & 2分/点 & 4秒 \\
\hline & $\begin{array}{l}\text { 固定測定 } \\
\text { 温湿度 }\end{array}$ & 作業環境 29点 & $\begin{array}{r}\text { RTR-53, } \\
\text { TR-72U }\end{array}$ & $\begin{array}{c}\text { 株デイアトド } \\
\text { ディ }\end{array}$ & - & 1分 \\
\hline \multirow{4}{*}{ 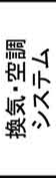 } & 給気温湿度 & 給気ダクト内 1ヶ所 & \multirow{4}{*}{ RTR-53 } & \multirow{4}{*}{$\begin{array}{c}\text { (株)テイアンド } \\
\text { ディ }\end{array}$} & \multirow{4}{*}{ - } & \multirow{4}{*}{ 1分 } \\
\hline & 排気温湿度 & $\begin{array}{l}\text { 排気ダクト内 } 3 \text { 所 } \\
\text { (各3点, 計 } 9 \text { 点) }\end{array}$ & & & & \\
\hline & 空調温湿度 & \begin{tabular}{|l} 
空調機 8台 \\
(各2点, 吹出し·吸込み)
\end{tabular} & & & & \\
\hline & 外気温湿度 & 屋外 1点 & & & & \\
\hline \multirow{2}{*}{ 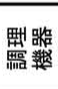 } & 水温 & \multirow[b]{2}{*}{ ケトル 5台 } & Testo 177 & (株)テス자- & - & 5秒 \\
\hline & 電力消費量 & & $\begin{array}{l}\text { KW4Mエコ } \\
\text { パワーメータ }\end{array}$ & $\begin{array}{l}\text { (株)パナソニッ } \\
\text { ク電エ }\end{array}$ & - & 1分 \\
\hline
\end{tabular}

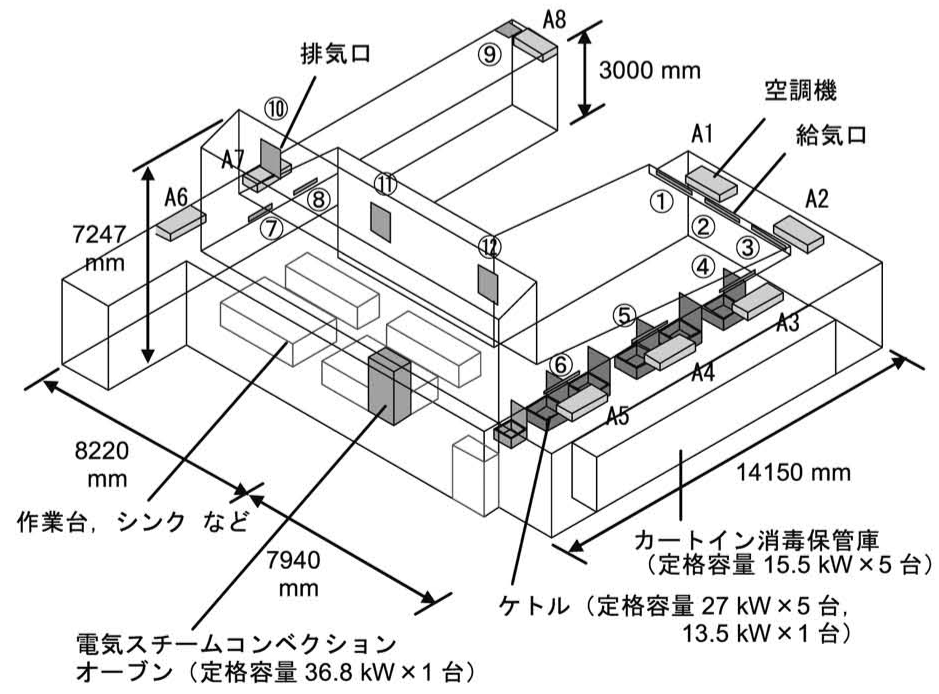

図 3 解析モデル 


\section{6. 解析結果と模擬負荷実験との比較}

\section{1 温度. 絶対湿度分布}

解析条件および解析モデルの妥当性について検討するため，まず 模擬負荷実験結果と, 実験時と同じ条件を与えた解析結果との比較 を行う。なお, 以降の実験および解析結果による温湿度・風速分布 は, いずれもケトルの縁から $1 \mathrm{~m}$ 程度離れた図 1 の A-A'断面につ いて示す。実験と解析による結果の比較を図 $4 \sim 6$ (室内温度分布, 室内絶対湿度分布, 室内風速分布)および図 7 にそれぞれ示す。ここ で図 7 は, 図 1 に示寸移動測定点と同じ位置の点の温湿度・風速デ 一タを解析結果より抽出し, 測定值と解析値との差を頻度分布とし て求めたものである。

空調稼動のない，換気量割合 $100 \%$ (Case B100)での実験結果で は, 天井付近や天井高の低い図の右側で温度がやや高く, 絶対湿度 は室中央部分で高くなる傾向にある。解析結果でも若干高い值では あるものの, 図の右側から中央の天井付近にかけて高温となる傾向 や, 室中央で高湿となる傾向が確認できる。また, 図 7 より温度は 6 割程度の測定点において, 測定值より解析值で $1^{\circ} \mathrm{C}$ 以上高い值を 示し, 解析において顕熱負荷が若干大となっているものと予想され るが, 絶対湿度は約 7 割が $0 \mathrm{~g} / \mathrm{kg}$ 中心 $(+1 \sim-1 \mathrm{~g} / \mathrm{kg})$ に分布しており, 測定值と解析值は近い值を示しているといえ, 解析結果は実験結果 をよく模擬している。

また, 図示は省略するが, 空調が稼動する Case D100 についても, 給気口(1) (3)の下部で機器からの熱上昇流が滞留し, 高湿となる傾 向を実験, 解析ともに共通して確認している。解析では空調風量に 機器定格值を用いたことから, 冷却効果が若干大となることが予想 され, 図 7 より,「測定值一解析値」の温度差は正側に分布する傾 向がみられるものの, 絶対湿度は $0 \mathrm{~g} / \mathrm{kg}$ を中心に分布している。

換気量割合 $30 \%$ で空調稼動のない Case B30 では, 実験と解析の 両者で, 高度の上昇に伴う温度上昇傾向がみられる。絶対湿度につ いては, 給気口下に位置する右端のケトル上部で高湿となる傾向が 解析結果ではみられるものの, 天井近傍の広い範囲で高湿化する現 象は, 両者に共通して確認できる。空調が稼動する Case D30 の温 度分布では, 空調吹出し気流の方向が実験と解析でやや異なってい た可能性があり, 高度上昇に伴う室温上昇傾向が実験結果では図中 の左側でも認められるのに対し, 解析結果では同様の傾向は確認で きない。しかしながら, 実験, 解析ともに絶対湿度は室全体で比較 的均質となる傾向を示している。図 7 によれば, 温度差は Case B30 で負側, D30 で正側に分布する傾向が若干みられるものの, 絶対湿 度については概ね B $30, D 30$ ともに $0 \mathrm{~g} / \mathrm{kg}$ を中心に分布しており,
表 6 解析条件

\begin{tabular}{|c|c|c|}
\hline \multicolumn{2}{|r|}{ CFDコード } & STREAM \\
\hline \multicolumn{2}{|r|}{ 乱流モデル } & 標準 $\mathrm{k}-\varepsilon$ モデル \\
\hline \multicolumn{2}{|r|}{$\begin{array}{l}\text { 移流項差分 } \\
\text { スキーム }\end{array}$} & QUICK \\
\hline \multicolumn{2}{|r|}{ 放射率 } & ケトル側面 : 0.3 , 壁面 : 0.9 \\
\hline \multirow[b]{2}{*}{ 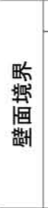 } & 気流 & 一般化対数則 \\
\hline & 熱·温度*1 & $\begin{array}{l}\text { 床面 : 熱伝導 } \\
\text { 天井 : 熱伝達係数 }\left[\mathrm{W} /\left(\mathrm{m}^{2} \cdot \mathrm{K}\right)\right] 2.20(\text { 夏期), } 2.28 \text { (冬期·中間期) } \\
\text { 外壁 : 熱伝達係数 }\left[\mathrm{W} /\left(\mathrm{m}^{2} \cdot \mathrm{K}\right)\right] 1.19 \text { (夏期), } 1.21 \text { (冬期·中間期) } \\
\text { 内壁 : 熱伝達係数 }\left[\mathrm{W} /\left(\mathrm{m}^{2} \cdot \mathrm{K}\right)\right] 1.58(\text { 夏期·冬期·中間期) } \\
\text { 外側面 : 温度対数則 } \\
\text { 作業台 : 断熱 }\end{array}$ \\
\hline \multirow{9}{*}{ 晎 } & & $\mathrm{k}=1.0 \times 10^{-10}\left[\mathrm{~m}^{2} / \mathrm{s}^{2}\right], \quad \varepsilon=1.0 \times 10^{-10}\left[\mathrm{~m}^{2} / \mathrm{s}^{3}\right]$ \\
\hline & \multirow{4}{*}{ 給気温湿度 ${ }^{* 2}$} & 実験: $30.3 \sim 33.3\left[{ }^{\circ} \mathrm{C}\right], 0.0157 \sim 0.0199\left[\mathrm{~kg} / \mathrm{kg}^{\prime}\right]$ \\
\hline & & 夏期 : $31.1\left[{ }^{\circ} \mathrm{C}\right], 0.0193\left[\mathrm{~kg} / \mathrm{kg}^{\prime}\right]$ \\
\hline & & 冬期 : $1.4\left[{ }^{\circ} \mathrm{C}\right], 0.0018\left[\mathrm{~kg} / \mathrm{kg}^{\prime}\right]$ \\
\hline & & 中間期 : $18.8\left[{ }^{\circ} \mathrm{C}\right], 0.0097\left[\mathrm{~kg} / \mathrm{kg}{ }^{\prime}\right]$ \\
\hline & \multirow{4}{*}{$\begin{array}{l}\text { 給気口 } \\
\text { (1) (9) }\end{array}$} & 換気量割合100\%: 2.4 3.7 [m/s] \\
\hline & & 換気量割合50\%: $2.2 \sim 2.8[\mathrm{~m} / \mathrm{s}]$ \\
\hline & & 換気量割合30\%: 1.1 1.7 [m/s] \\
\hline & & 換気量割合20\%: 0.5 1.4 [m/s] \\
\hline \multirow{4}{*}{ 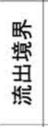 } & \multirow{4}{*}{$\begin{array}{l}\text { 排気口 } \\
\text { (10) (12) }\end{array}$} & 換気量割合 $100 \%: 1.5[\mathrm{~m} / \mathrm{s}]$ \\
\hline & & 換気量割合 $50 \%: 0.8[\mathrm{~m} / \mathrm{s}]$ \\
\hline & & 換気量割合 $30 \%: 0.5[\mathrm{~m} / \mathrm{s}]$ \\
\hline & & 換気量割合 $20 \%: 0.3[\mathrm{~m} / \mathrm{s}]$ \\
\hline \multirow[b]{2}{*}{ 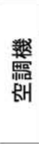 } & 吹出し風速 ${ }^{* 6}$ & $\mathrm{~A} 1 \sim \mathrm{A} 7: 4.2[\mathrm{~m} / \mathrm{s}], \mathrm{A} 8: 2.1[\mathrm{~m} / \mathrm{s}]$ \\
\hline & $\begin{array}{l}\text { 吹出し } \\
\text { 温湿度 }\end{array}$ & $\begin{array}{l}\text { 実験 : 各ケースの実験中の平均値を用いた。 } \\
\text { 各季節の解析: 各解析ケースで設定した空調能力に従って, 除湿. } \\
\text { 冷却および加熱されて吹出すよう設定している。各ケースの吹出し } \\
\text { 空気の温湿度を注7) 付表1にに示す。 }\end{array}$ \\
\hline \multicolumn{2}{|r|}{ 発熱境界 } & $\begin{array}{c}\text { 実験 (対流熱伝達係数) : } 75\left[\mathrm{~W} /\left(\mathrm{m}^{2} \cdot \mathrm{K}\right)\right]^{* 7} \\
\text { 各季節の解析 : } 7.6[\mathrm{~kW}]\end{array}$ \\
\hline \multicolumn{2}{|r|}{$\begin{array}{l}\text { 湿度境界 } \\
\text { (䝷量流束) } \\
\end{array}$} & $\begin{array}{c}\text { 実験 : } 3.31\left[\mathrm{~g} /\left(\mathrm{m}^{2} \cdot \mathrm{s}\right)\right] \\
\text { 各季節の解析 : } 2.85\left[\mathrm{~g} /\left(\mathrm{m}^{2} \cdot \mathrm{s}\right)\right]\end{array}$ \\
\hline \multicolumn{3}{|c|}{$\begin{array}{l}\text { *1 使用材料から熱貫流率を算出し, 熱伝達係数として与えている。 } \\
\text { *2 給気温湿度とは, 給気口(1) 9人り導入される外気の温湿度を指す。実験時の解析では, 実験実 } \\
\text { 施中の給気温湿度の測定値を与えた。各季節の解析時には, 調理時間帯と考えられる年前10時の } \\
\text { 高松市における標準気象テタ(TAC5\%)を用いた。 }\end{array}$} \\
\hline \multicolumn{3}{|c|}{ 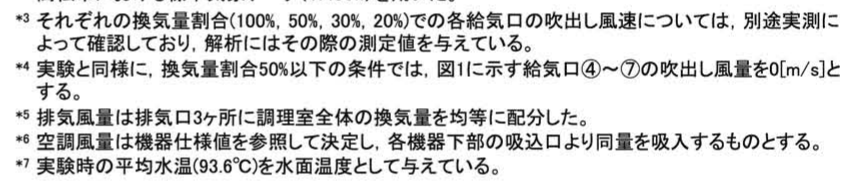 } \\
\hline
\end{tabular}

表 7 解析ケース

\begin{tabular}{c|c|c|c}
\hline case & 外気条件 & 換気量割合 & 空調能力 $^{* 1}$ \\
\hline 1 & 夏期 & $100 \%$ & $13 \mathrm{~kW}$ \\
\hline 2 & $\prime \prime$ & $30 \%$ & $6 \mathrm{~kW}$ \\
\hline 3 & $\prime \prime$ & $20 \%$ & $4 \mathrm{~kW}$ \\
\hline 4 & 冬期 & $100 \%$ & $14 \mathrm{~kW}$ \\
\hline 5 & $\prime \prime$ & $30 \%$ & $5 \mathrm{~kW}$ \\
\hline 6 & $\prime \prime$ & $20 \%$ & $4 \mathrm{~kW}$ \\
\hline 7 & 中間期 & $100 \%$ & - \\
\hline 8 & $\prime \prime$ & $50 \%$ & - \\
\hline 9 & $\prime \prime$ & $30 \%$ & - \\
\hline
\end{tabular}

*1 図1に示す空調機 $\mathrm{A} 1$ 〜 $\mathrm{A}$ の各々の空調能力であり, それぞれ室温が $25^{\circ} \mathrm{C}$ 程度にな るように値を設定している

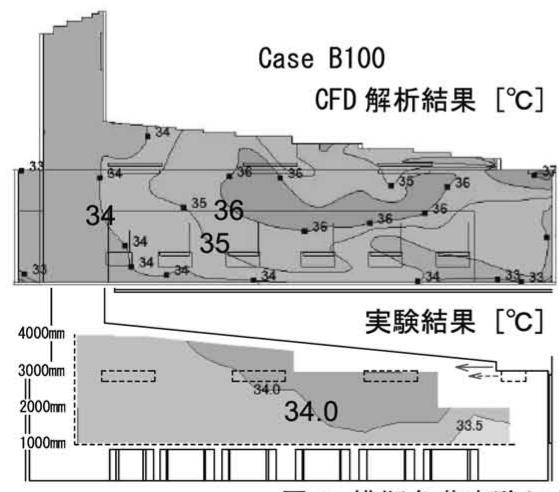

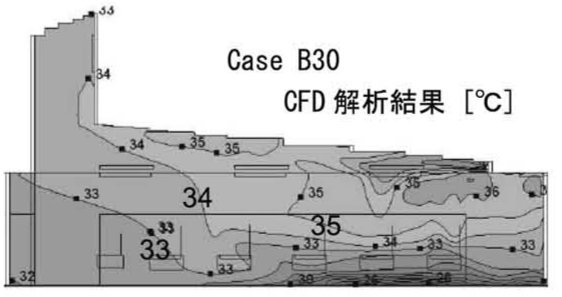

実験結果 $\left[{ }^{\circ} \mathrm{C}\right]$

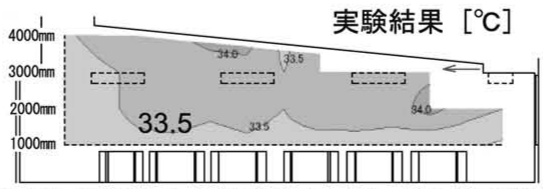

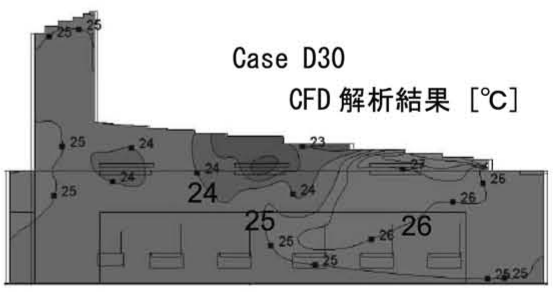

実験結果 $\left[{ }^{\circ} \mathrm{C}\right]$

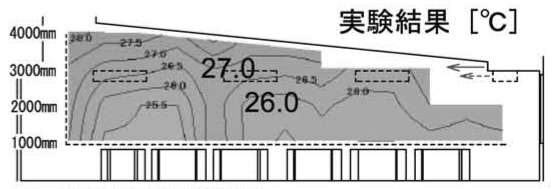

図 4 模擬負荷実験および CFD 解析による温度分布（上:CFD 解析結果，下:実験時測定結果） 

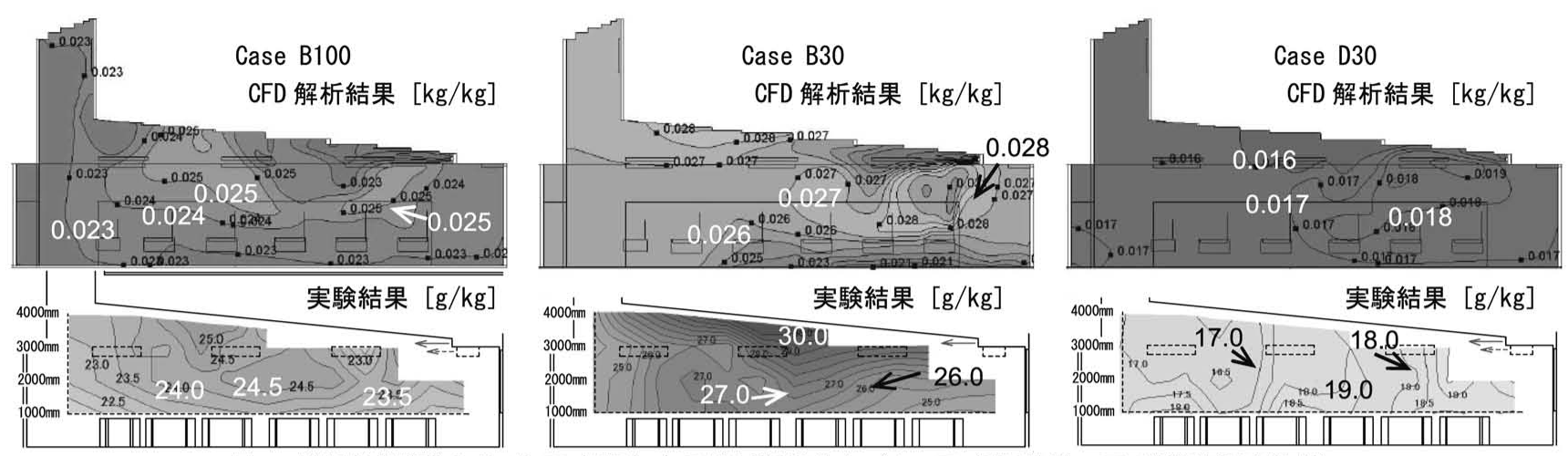

図 5 模擬負荷実験および CFD 解析による絶対湿度分布 (上:CFD 解析結果, 下: 実験時測定結果)
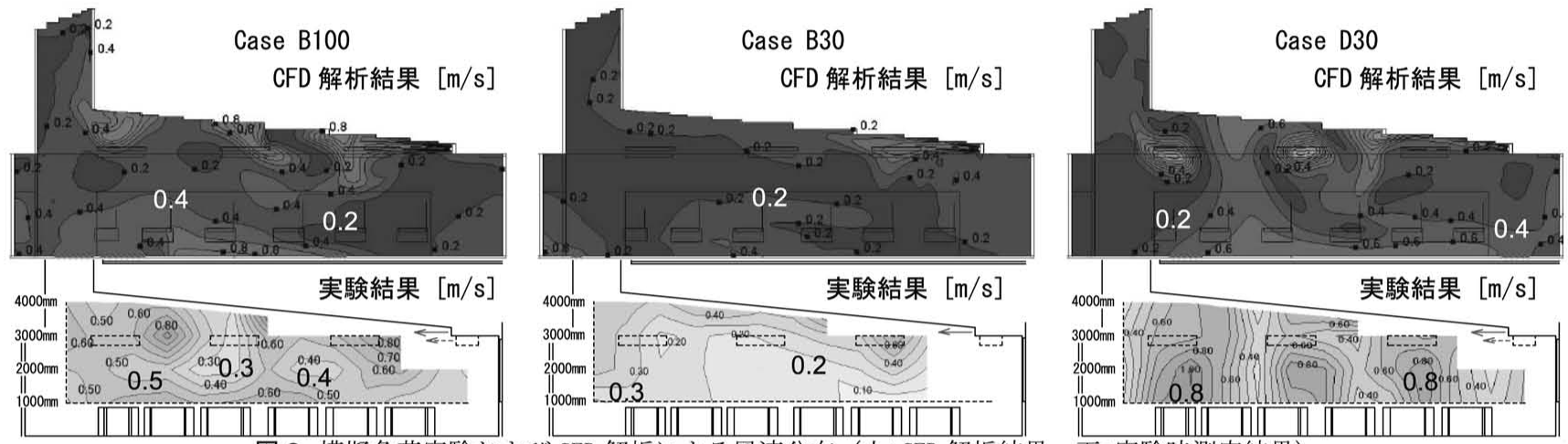

図 6 模擬負荷実験およびCFD 解析による風速分布（上:CFD 解析結果，下:実験時測定結果
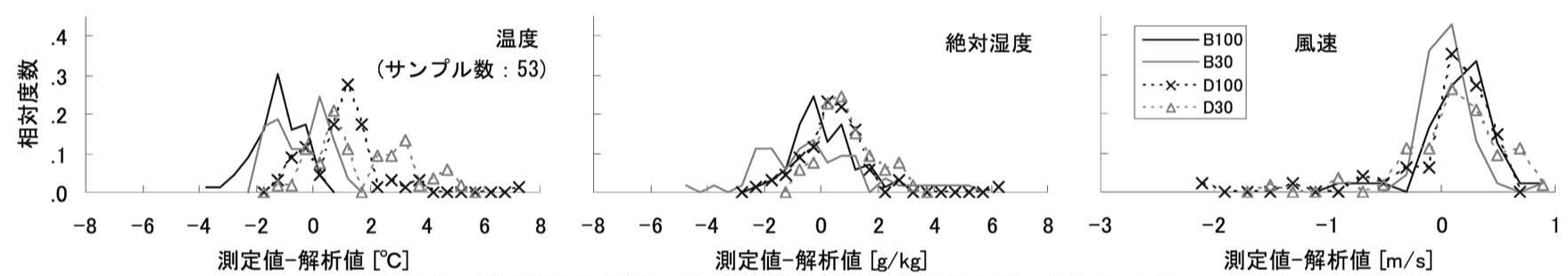

図 7 測定値と解析值の差（※ 測定值から解析值を引いた值を示す）

実験結果と解析結果で顕著な差はみられない。

\section{2 風速分布}

換気量割合 $100 \%$ (Case B100)では, 床上 $3 \mathrm{~m}$ の地点で図の手前 から奥へ吹出す給気口(4) (6の吹出気流による風速の増大が実験・ 解析両結果に共通してみられる。また, いずれのケースでも, 実験 結果で右側のケトル上部における高さ $2 \mathrm{~m}$ 付近の風速が解析結果よ り若干高速となる傾向がみられる。しかしながら, Case B30, D30 ともに，給気口の一部を閉鎖したことにより，実験結果では $100 \%$ の場合より風速が減少しており, 解析結果でも同様の傾向が認めら れ, いずれのケースにおいても, 測定值と解析值の差が小さいこと が図 7 からも確認できる。

以上の検討から, 解析においては顕熱負荷および空調による冷却 効果が若干大となった影響により, 測定值と解析值で $+1 \sim-1{ }^{\circ} \mathrm{C}$ の温 度差がみられるものの, 室内全体の温湿度 - 気流分布に著しい差異 は認められないことから, 異なる換気量条件が室内温熱環境に及ぼ 寸影響を検討する上で，CFD 解析の妥当性が確認できた。

\section{7. 換気量低減時の室内温熱環境}

実際の調理を想定した負荷発生時注 6) において，換気量の違いが TAC 5\%の各外気条件下(夏期・冬期・中間期)で室内温熱環境に及ぼ
す影響を検討するために, 表 7 に示す 9 ケースについて解析を実施 した。各ケースにおける空調能力は, 室温が $25{ }^{\circ} \mathrm{C}$ 程度となるよう に設定しており, 換気量の低減に伴い低下させている。なお, 夏期 には空調によって, 外気負荷に加え, 発生顕熱および潜熱負荷を除 去すること，冬期には発生顕熱が室内を加熱することを想定してい る。また，中間期は外気の温熱環境条件が良好であると考えられる ため, 空調は稼動させず, 換気量の低下による換気ファン出力の低 減について考察を行う。なお，各季節・各換気量条件下での室内温 熱環境を実験により把握することも考えられたが，実際に運用され ている施設であり, 時間的余裕が無く, また給気外気条件を一定に 維持することが困難であるため,ここでは CFD 解析を用いている。

\section{1 夏期}

Case 1 3 の夏期の解析結果を図 8 に示す。なお, 以降の分析に おいて, 発生顕熱・潜熱および各換気量割合での外気負荷に詨寸る 空調の効果を検討することに主眼を置いているため, 室内気流分布 の図示を省略する。温度分布では, Case 1 3 のいずれも, 空調設計 温度である $25{ }^{\circ} \mathrm{C}$ 前後の值を示している。また, いずれも図右上の 天井付近で高温域が形成されており, 給気口からの高温吹出しによ る影響が確認できる。絶対湿度分布では, $0.018 \mathrm{~kg} / \mathrm{kg}$ 以上の領域 に着目するなら, Case 1 では室右側の約 1/4, Case 2 では室の右半 

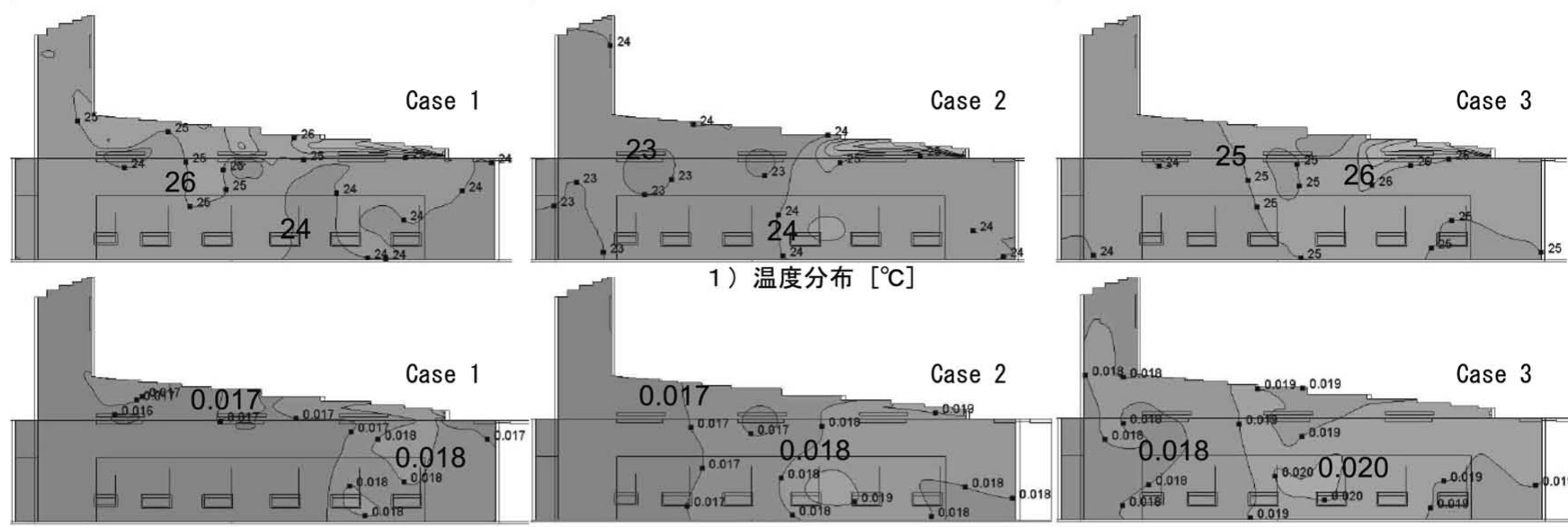

1）温度分布 $\left[{ }^{\circ} \mathrm{C}\right]$
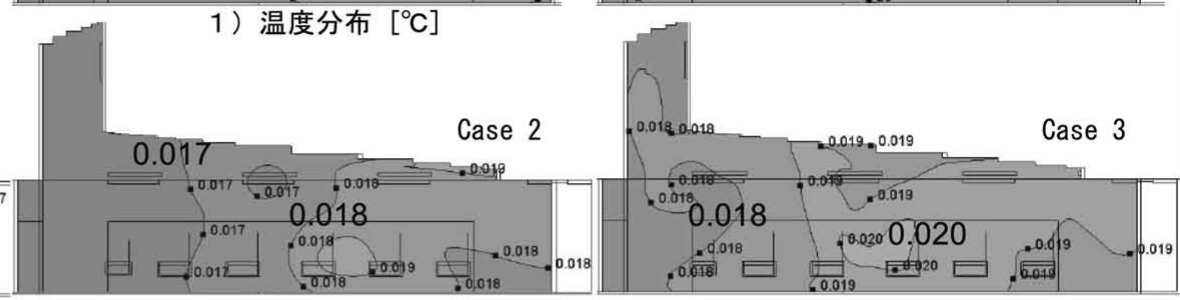

2 ) 絶対湿度分布 $[\mathrm{kg} / \mathrm{kg}]$

図 8 夏期の CFD 解析結果
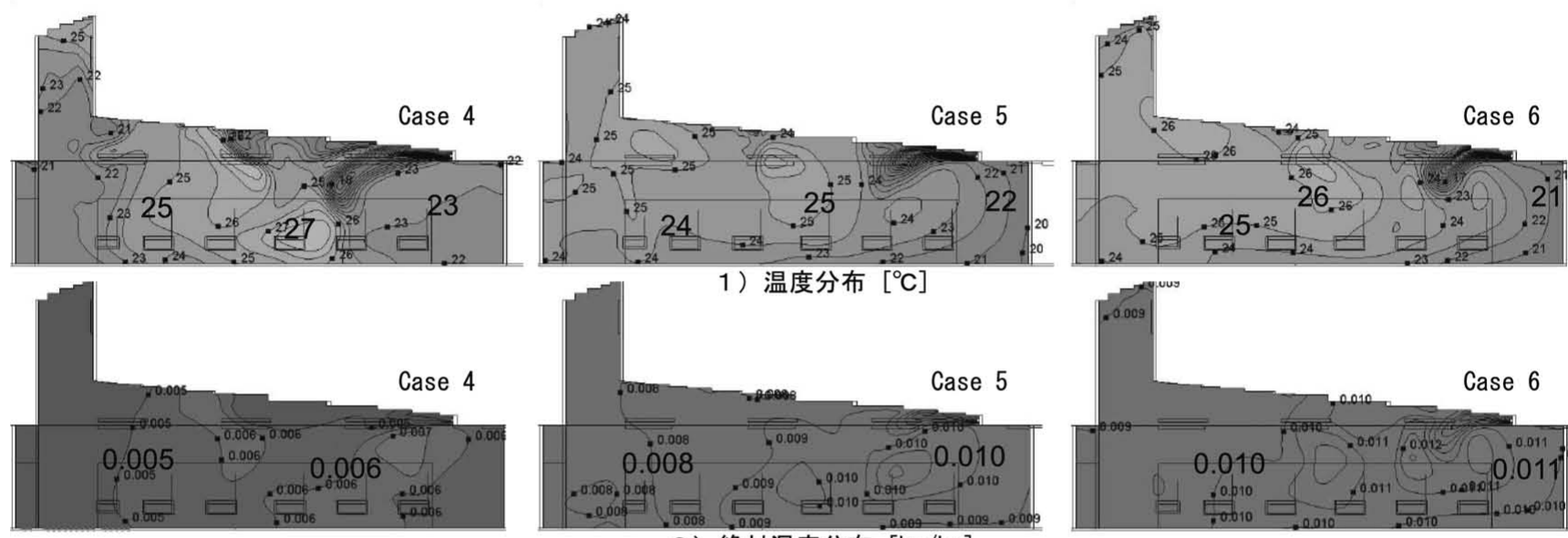

2 ）絶対湿度分布 $[\mathrm{kg} / \mathrm{kg}]$

図 9 冬期の CFD 解析結果

分, Case 3 では室右側の $3 / 4$ 程度と, 換気量の低下に伴い高湿度領 域が拡大していることが確認できる。また, Case 3 の室中央のケト ル上部において, $0.020 \mathrm{~kg} / \mathrm{kg}$ と高湿な值を示している。

ここで, 表 8 の各解析ケースにおける空調処理熱量によれば, Case 1，2 では発生全熱負荷と外気全熱負荷の和が空調処理全熱量 とほぼ同等であり, 発生負荷を全て空調が処理していることがわか る。一方, Case 3 では発生顕熱負荷と外気顕熱負荷は空調によって 処理されているものの, 空調処理潜熱が発生潜熱を若干下回ってい ることにより, 室内が高湿となっていると考えられる。また, 図示 は省略するが, 室内風速分布より, Case 3 では Case 2 より, 吹出 し風速が小さく, 空調機からの低温吹出しの影響により室中央部で 下降気流が形成される傾向が顕著にみられるため, 室内の発生潜熱 を排気口に誘導しづらいことも考えられる。

以上の結果から, 初期換気量の $20 \%$ まで低減した場合には負荷の 排出に若干の問題が生じるものの，30\%まで低減した場合は，初期 換気量条件の半分以下の空調能力で概ね同様な室内温熱環境を維持 できるといえる。ただし，いずれのケースでも潜熱処理熱量が大き く顕熱比がかなり小となるため, 能力を低減させる際の電力消費量 の削減効果が大きく現れない可能性が示唆される。

\section{2 冬期}

Case 4 6 の冬期の解析結果を図 9 に示す。温度分布では, 室中 央からやや右よりにかけて $25 \sim 27{ }^{\circ} \mathrm{C}$ の值を示すのに対し, 図右端
表 8 空調による処理熱量

\begin{tabular}{|c|c|c|c|c|c|c|c|c|c|}
\hline & \multicolumn{3}{|c|}{ 発生負荷 [kW] } & \multicolumn{3}{|c|}{ 外気負荷 ${ }^{* 1}[\mathrm{~kW}]$} & \multicolumn{3}{|c|}{ 空調処理熱量*2 [kW] } \\
\hline & 顕熱 & 潜熱 & 全熱 & 顕熱 & 潜熱 & 全熱 & 顕熱 & 潜熱 & 全熱 \\
\hline case 1 & 7.6 & 34.1 & 41.7 & 23.2 & 28.9 & 52.1 & -37.4 & -73.9 & -111.2 \\
\hline case 2 & 7.6 & 34.1 & 41.7 & 6.6 & 6.3 & 12.8 & -16.5 & -42.1 & -58.5 \\
\hline case 3 & 7.6 & 34.1 & 41.7 & 6.4 & 4.2 & 10.6 & -11.6 & -29.0 & -40.6 \\
\hline case 4 & 7.6 & 34.1 & 41.7 & -94.7 & -27.1 & -121.8 & 114.4 & -0.2 & 114.3 \\
\hline case 5 & 7.6 & 34.1 & 41.7 & -26.4 & -17.9 & -44.4 & 43.7 & -4.4 & 39.3 \\
\hline case 6 & 7.6 & 34.1 & 41.7 & -20.5 & -16.4 & -36.9 & 37.6 & -3.6 & 33.9 \\
\hline
\end{tabular}

の壁近傍では 20 22 ${ }^{\circ} \mathrm{C}$ と比較的低温になっており，空調気流の影 響が及びにくいことが予想される。また，給気口からの低温吹出し により，室右側上部で $20{ }^{\circ} \mathrm{C}$ 以下の低温領域が形成される傾向にあ り, 給気吹出し風速の大きい Case 4 (換気量割合 $100 \%$ )でより顕著 である。さらに Case 4 では図中央のケトル付近で $27{ }^{\circ} \mathrm{C}$ と高い值を 示しているが，これは給気口(1) (6)の低温吹出し気流によってケト ル上部の風速值が高くなり，発生負荷による熱上昇流が阻害され， ケトル上面下部でも高温域が形成されるためと考えられる。しかし ながら, 室温は Case 4 6 のいずれも概ね $25{ }^{\circ} \mathrm{C}$ 程度であり, 表 8 においても空調加熱量は外気顕熱負荷より大となっている。絶対湿 度分布では，換気量の低下に伴い図中の右側で高湿化する傾向にあ るが，天井面温度はいずれのケースでも給気口付近を除いて，概ね $18{ }^{\circ} \mathrm{C}$ 以上露点温度を上回っていることから, 天井面で結露は発 生しないものと想定された。 

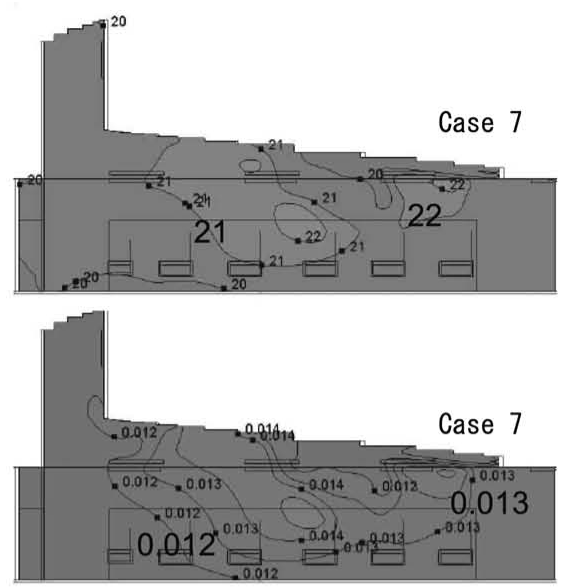

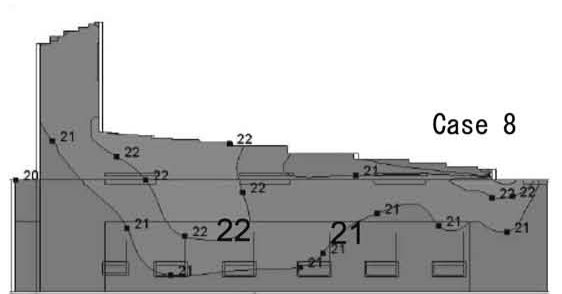

1）温度分布 $\left[{ }^{\circ} \mathrm{C}\right]$

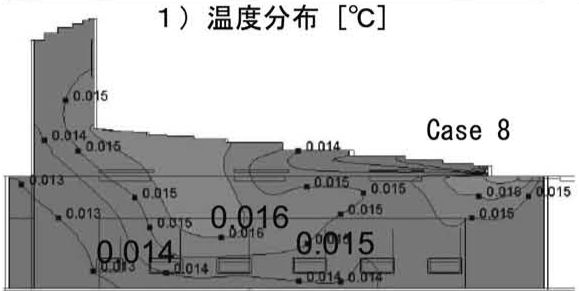

2 ）絶対湿度分布 $[\mathrm{kg} / \mathrm{kg}]$

図 10 中間期の CFD 解析結果
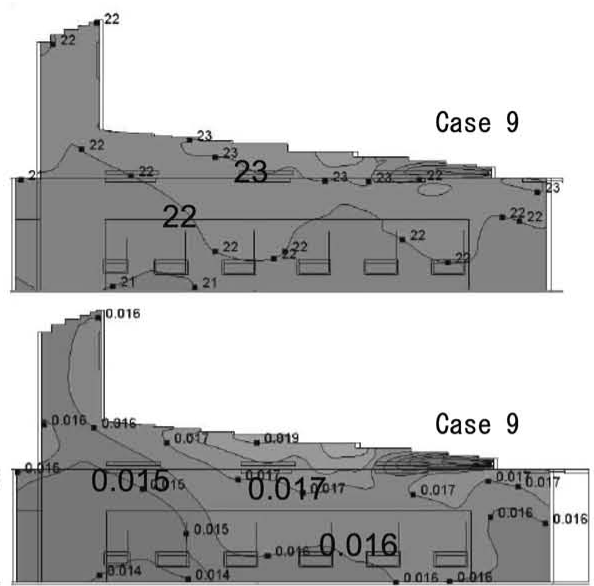

これにより，冬期では外気が低湿なため換気量が少量でも除湿効 果が高く, 負荷発生による室内の湿度上昇は抑制されると考えられ るため, 換気量割合 $20 \%$ 期換気量と同程度の温熱環境を維持しながら, 初期換気量の $1 / 3$ 以 下の空調能力に低減することが可能であるといえる。

\section{3 中間期}

Case 7 9 の中間期の解析結果を図 10 に示す。いずれの換気量条 件においても, 室温は $21^{\circ} \mathrm{C}$ 前後となっており, 絶対湿度は換気量の 減少に伴って上昇する傾向が確認できる。また, 換気量割合 $30 \%$ の Case 9 では, 発生負荷が上部空間に滞留しやすく, A 断面中央 の天井付近で相対湿度が $100 \%$ に達しており, 給気風速の不足が示 唆される。一方, 換気量割合 $50 \%$ の Case 8 では, 天井付近で高湿 となる状況は確認されず, 給気口(1) (3)の吹出しにより発生負荷を A 断面の図の左上にある排気口に誘導していると考えられる。

以上の結果から, 換気量割合 $50 \%$ では, $30 \%$ と比較して発生負 荷による天井付近の温湿度上昇が緩和される結果が得られた。中間 期では, 室内温熱環境を良好な状態に維持し, 発生負荷を排気口に 誘導するため, 夏期や冬期より大きな換気量を要すると考えられる。 夏期と同様に換気量割合を $30 \%$ とし, 空調稼動による除湿を期待す ることも可能であるが, 換気に要する機器出力は $30 \%$ な゙ $0.01 \mathrm{~kW}$ であるのに対し， $50 \%$ では $0.46 \mathrm{~kW}$ 程度と両者とも小さな值であ ることから, 中間期においては空調稼動より換気量の増加によって 対処するほうが省エネルギー的観点からはより有効と考えられる。

\section{8. 結論}

全電化学校給食施設における欴房内の適切な換気量を検討するた め, 高天井を有する実際の調理室を対象として, 調理機器の定格電 気容量により算出した種々の換気量条件下での解析を各季節で行い, 以下の知見を得た。

1）平成 19 年と 20 年の夏期に実施した模擬負荷実験と同一の条 件で CFD 解析を行い, 実験結果と解析結果を比較することによ り, CFD 解析の適用可能性について検証し, 異なる換気量条件 での室内温熱環境に及ぼす影響を把握する上で CFD 解析が有用 であることを確認した。

2）夏期の外気条件下の場合, 換気量割合 $20 \%$ は発生熱負荷の排
出に若干支障が認められたが，換気量割合 30 \%では空調能力を 低減させながら, 初期換気量割合と同様な室内温熱環境を獲得 できることを示した。

3）一方, 冬期については, 外気が低湿で高い除湿効果が期待さ れるため，換気量割合 $20 \%$ の条件でも，初期換気量割合と同様 な室内温熱環境を維持しながら, 空調能力を $1 / 3$ 以下に低減する ことが可能であることを示した。

4）外気負荷の少ないことから空調稼動を停止することを想定 した中間期においては，換気量割合 $30 \%$ では発生負荷の排出に 若干の支障が認められ，夏期や冬期より大きな換気量割合 $50 \%$ の条件が妥当であると考えられた。ただし，換気量割合 $30 \%$ と 比較して換気に要するエネルギーはごくわずかな増加にとどま ることを確認した。

対象とした施設のように外気を直接導入し，空調室内機により温 熱環境を制御する場合，夏期，冬期の換気量の削減により外気負荷 を大幅に低減することが可能であり, 室内温熱環境を維持しながら, 省エネルギーを実現する可能性が示唆された。一方, 空調負荷の少 ない中間期では, 初期換気量よりは小となるものの換気量を夏期や 冬期より増加させる必要があるが, 換気に要するエネルギーの増加 はごくわずかであることを示した。

\section{謝辞}

本研究は広島大学および四国電力侏), (侏四電技術コンサルタント との共同研究によるものであり，関係者の方々に多大なるご協力を いただいた。ここに記し，謝意を表する。

\section{本論文に関する既発表論文}

*1）島本裕子, 村川三郎, 西名大作, 青野政信, 竹川忠克, 名倉義行 : 全電 化学校給食施設の換気システムが屍房内温熱環境に及ぼす影響に関する研 究, その 1 調査概要と夏期における測定結果, 日本建築学会中国支部研 究報告集，第 31 巻，pp.423.1-423.4，2008.3

*2）島本裕子, 村川三郎, 西名大作, 青野政信, 竹川忠克, 名倉義行 : 全電 化学校給食施設の換気システムが朁房内温熱環境に及ぼす影響に関する研 究, その 2 換気量条件による㕑房内温熱環境の形成, 日本建築学会中国 支部研究報告集, 第 32 巻, pp.413.1-413.4, 2009.3

*3）島本裕子, 村川三郎, 西名大作, 青野政信, 宇草和義, 名倉義行 : 全電 化学校給食施設の換気システムが府房内温熱環境に及ぼす影響に関する研 究, その 3 模擬負荷実験と数值流体解析による結果の比較, 日本建築学 会中国支部研究報告集，第 33 巻, pp.420.1-420.4，2010.3 


\section{参考文献}

1）豊村幸毅, 甲谷寿史, 山中俊夫, 桃井良尚, 相良和伸, 高野翔太 : 低放 射·集中排気型厨房機器を用いた業務用厨房の CFD 解析手法に関する研究 第 1 報 測定值に基づく境界条件作成とフード捕集率の CFD 解析, 空気調 和・衛生工学会論文集, No.186, pp.13-21, 2012.9

2) 国土交通省大臣官房庁営繕部設備 - 環境課監修 : 建築設備設計基準（平 成 21 年版）, p.458

3）宇野勇治, 渡邊慎一, 堀越哲美, 野本智子, 田中稲子 : 異なるふたつの 形式の学校給食調理施設における温熱環境と作業行動の比較調査, 日本建 築学会環境系論文集，第 576 号, pp.49-56, 2004.2

4) 村川三郎, 西名大作, 熊尾隆丈, 宇田川博司, 清田誠良, 西扸暢夫, 近 都州彦: 全電化学校給食施設における換気・空調システムの評価実験 そ の 2 天井型給排気システムによる旡房内環境評価, 日本建築学会中国支部 研究報告集, 第 27 巻, pp.473-476, 2004.3

5）本多順子, 甲谷寿史, 山中俊夫, 桃井良尚, 相良和伸 : 住宅用ガスコン 口における鍋上方の熱上昇気流性状に関する研究（その 5) 径の異なる鍋 におけるセンターフードの捕集率予測, 空気調和・衛生工学会大会学術講 演論文集, pp.3077-3080, 2012.9

6) 荻田俊輔, 近藤靖史, 吉野一, 西川向一 : 従来の換気 - 空調方式と天井 吹出し型置換換気 · 空調方式の比較 業務用旡房における置換換気 - 空調 方式に関する研究(その 2), 日本建築学会環境系論文集, 第 75 号, pp.179-187, 2010.2

7）日浅英成, 白石靖幸, 村川三郎, 清田誠良, 西胤暢夫 : CFD 解析による 業務用電化厨房の排気性能評価に関する研究 その 3 天井型排気システム の解析, 日本建築学会大会学術講演梗概集, D-2, pp.729-730, 2005.7

8）村川三郎, 清田誠良, 西扸暢夫, 柿本晋太朗, 熊尾隆丈, 森本旭 : 業務 用電化厨房機器の発生負荷と適正排気量に関する研究 第 1 報 各種旡房 機器からの発生熱量, 空気調和・衛生工学会論文集, No.95, pp.1-13, 2004.10

9）田中稲子, 森秀樹, 堀越哲美, 渡邊慎一, 宇野勇治 : 寒冷地における電 化履房を持つ学校給食施設の温熱環境特性, 日本建築学会大会学術講演梗 概集，D-2, pp.77-78，2006.9

10）藤田美和子, 近藤靖史, 吉野一, 荻田俊輔 : 業務用電化厨房の換気・空 調に関する研究（その 8) 置換換気システムにおける天井排気の有効性, 日本建築学会大会学術講演梗概集, D-2, pp.657-658, 2008.9

11）近藤靖史, 赤林伸一, 坂口淳, 荻田俊輔, 平塚正啓 : 業務用厨房の高効 率換気・空調システムに関する研究 その 15 実測・実験による夏期の朁 房内温度等の検討, 日本建築学会大会学術講演梗概集, D-2, pp.601-602, 1997.9

12）坂口淳, 赤林伸一, 近藤靖史, 川瀬貴晴, 荻田俊輔 : 実大実験による換 気・空調効率の測定, 業務用欴房の高効率換気・空調システムに関する研 究その 1 日本建築学会計画系論文集, 第 534 号, pp.33-40, 2000.8

13）長田匡史, 秋元孝之, 堀川晋, 市山諭, 堤仁美 : 業務用厨房における天 井換気システムの特性と制御に関する研究, 日本建築学会大会学術講演梗 概集，D-2，pp.747-748，2006.9

14）津村勇次, 甲谷寿史, 相良和伸, 山中俊夫, 桃井良尚 : アイランド型キ ッチンを有する LDK の換気計画に関する研究（その 4) 鍋側面気流モデル を用いた CFD 解析によるセンターフードの捕集率予測, 日本建築学会近畿 支部研究報告集, pp.305-308, 2010.5

15）西名大作, 村川三郎, 清田誠良, 西扸暢夫, 近都州彦, 植村義幸 : 全電 化学校給食施設における旡房機器の使われ方とエネルギー消費量の解析, 空気調和・衛生工学会論文集, No.112, pp.1-11, 2006.7
注

注 1）初期換気量は，室内の各給気口で測定した。具体的には，給気口が扁 平で中央に風量が著しく偏るため, 給気口の周囲を吹出し気流が拡散しな いように密閉し作成した正方形断面の簡易ダクトにビニールシートで気流 を導き, 断面に格子状に設置した 16 点での測定值に基づいて平均風速を算 出し, 断面面積を乗じて算出した。

注 2）表 3 に示すケトルの日平均出力の最大值は, 平成 19 年 9 月 平成 20 年 6 月における測定值をもとに, 算出している。

注 3）換気量は, 予めインバータで回転数を数段階変更して各給気口で風速 測定を行い，平均風速に各給気口面積を乗じた風量と回転数との関連を確 認し, 設定した換気量に対応する回転数に調整した。なお, 換気量割合 $30 \%$ の条件では, 図 1 に示す給気口(4) (7)を閉鎖することにより, 各給気口での 極端な風速減少を防ぐとともに, 発生負荷を排気口に誘導する流れを一方 向化し, より効率よく排気が行われるよう配慮した。

注 4）詳細な格子分割数は, $2769480(196(\mathrm{X}) \times 157(\mathrm{Y}) \times 90(\mathrm{Z}))$ である。

注 5）放射と対流の連成解析を行っており，放射計算はモンテカルロ法を用 いて形態係数を求める VF 法を採用し，放射率はステンレス鋼が用いられ ているケトル側面を 0.3 , 調理室壁面を 0.9 とした。なお, 会議室に面する 調理室の壁面は見学用ガラスがはめ込まれているが, 調理室の温熱環境に 及ぼす影響は比較的小さいものと考え, 他の壁面と同様に放射率(0.9)を設 定した。調理室の出入り口も同様である。

注 6) 6 章の負荷発生量は, 実験時の測定結果と解析結果の対応を確認する ため, 実験時の值を用いている。しかしながら, 実運用時における長期測 定により，実験時のような 5 台のケトルによる煮込み調理が同時に行われ ることが稀なことが把握できた。そのため, 6 章と 7 章では発生熱量を変 更した。 7 章で用いた值の算出手順を以下に示す。まず, 実運用時におけ る給排気の温湿度測定データから発生熱量の最大值を算出した結果, 43.4 $\mathrm{kW}$ を得た。一方, 既往研究 8) では, ケトルが機器定格で稼働する場合の 調理帯 2 (ケトル等に代表される『開放型調理機器』の発生負荷の経時変化 パターンのうち, 使用開始直後の小負荷発生時と定常的な負荷発生時を除 いた, 過渡状態を経て最大值を示すまでの水温 $80 \sim 95{ }^{\circ} \mathrm{C}$ の温度帯)の発生 熱量は $69.5 \mathrm{~kW}$ と示されている。しかしながら, 既往研究 15）によれば実 運用時において定格で連続して稼働することはほとんどみられないことか ら,これにケトルの 1 時間間隔の最大負荷率 0.6 を低減率として乗じると, $41.7 \mathrm{~kW}$ と算出される。この值は実運用時の測定データから算出した発生 熱量(43.4 kW)とほぼ同じであることから, 既往研究に基づいて算出した熱 量 $41.7 \mathrm{~kW}$ を条件として採用した。そこで，境界条件は，ケトル水面に顕 熱 $7.6 \mathrm{~kW}$ と同等の熱量が発生するよう熱伝達係数を各ケースで調整し, 潜熱発生量として質量流束 $2.85 \mathrm{~g} /\left(\mathrm{m}^{2} \cdot \mathrm{s}\right)$ を設定した。なお, 上述した最大 負荷率 0.6 はケトル電力消費量の実測結果から得られた值に基づいている。 注 7) 空調処理熱量を算出する際に用いた空調機吹出し温湿度を付表 1 に示 す。

付表 1 解析時の空調吹出し温湿度

\begin{tabular}{c|r|r}
\hline Case & 温度 $\left({ }^{\circ} \mathrm{C}\right)$ & 絶対湿度 $(\mathrm{g} / \mathrm{kg})$ \\
\hline 1 & 18.5 & 12.7 \\
\hline 2 & 21.6 & 15.4 \\
\hline 3 & 23.3 & 17.1 \\
\hline 4 & 40.7 & 5.4 \\
\hline 5 & 29.3 & 9.2 \\
\hline 6 & 28.2 & 9.9 \\
\hline
\end{tabular}

（2012年11月 9 日原稿受理，2013年 4 月17日採用決定） 